\title{
İlköğretimde Ekonomiyle İlgili Ĕgitsel Niteliklerin Kazandırılmasına İlişkin Öğrenci Görüşleri ${ }^{1}$
}

\begin{tabular}{lccc}
\hline MAKALE TÜRÜ & Başvuru Tarihi & Kabul Tarihi & Yayın Tarihi \\
Araştırma Makalesi & 02.11 .2018 & 30.04 .2019 & 01.05 .2019 \\
\hline
\end{tabular}

Hakkı Toy

Ankara Üniversitesi

$\ddot{\mathrm{O} z}$

$\mathrm{Bu}$ araştırma, ilköğretimde öğrencilere kazandırılması amaçlanan ekonomiyle ilgili üretkenlik ve tüketim bilincine sahiplik eğitsel niteliklerinin öğrencilere hangi derecede kazandırıldığını öğrencilerin görüşlerinden yola çıkarak saptamayı amaçlamaktadır. Tarama modelinde olan bu araştırmada, nicel çözümleme kullanılmıştır. Bu araştırmanın hedef evrenini 2011-2012 öğretim yılında Ankara'nın merkez dokuz ilçesinde bulunan ilköğretim okullarındaki öğrenciler oluşturmaktadır. Bu hedef evrenin temsili, tabakalı olarak örnekleme yoluyla belirlenen merkez ilçelerdeki ilköğretim okullarında öğrenim gören ve rastgele ulaşılan 382 öğrenciyle sağlanmıștır. Araștırmada öğrenci görüşlerine ilișkin veriler, bu amaçla geliștirilen anket aracılığıyla toplanmıştır. Araştırmanın bulguları, anketteki ifadelere katılım derecesi, aritmetik ortalama $(\bar{x})$ ve standart sapma (ss) değerleri kullanılarak yorumlanmıştır. Araştırma sonucunda, ilköğretim düzeyinde üretkenlik ve tüketim bilincine sahiplik gibi ekonomiyle ilgili eğitsel niteliklerin öğrencilere yeterli derecede kazandırıldığı sonucuna ulaşılmıştır.

Anahtar sözcükler: Eğitsel nitelik, üretkenlik, tüketim bilincine sahiplik.

${ }^{1}$ Toy, Hakkı (2012) "İlköğretimin Öğrencilere Kazandırmayı Amaçladığı Ekonomiyle İlgili Eğitsel Nitelikler Konusunda Öğrenci Görüşleri” adlı, Prof. Dr. Kasım Karakütük'ün danışmanlığında tamamlanan yüksek lisans tezinden üretilmiștir.

${ }^{2}$ Sorumlu Yazar: Doktora Öğrencisi, Eğitim Bilimleri Enstitüsü, Eğitim Yönetimi ve Politikası Anabilim Dal1, E-posta: hakkitoy@ hotmail.com, https://orcid.org/0000-0002-2440-825X 
Tarih boyunca insanın en önemli etkinliği, işi ve toplumsal ilişki biçimlerinden biri olarak eğitime ve eğitim olgusuna yönelik birden çok bilimsel açıklama girişimi olduğu bilinmektedir. Bilindiği gibi, eğitim olgusuna ve etkinliklerine ilişkin, yaklaşımlar ve bilimsel açıklama çabaları, belirli bir felsefe ve düşünsel zemin üzerinden yola çıkarak kurulmuştur. Söz gelimi, eğitimsel gerçekliğin diğer toplumsal olgular gibi bir özü olduğunu düşünen ya da varsayan yaklaşımlarda, eğitimsel ilişki ve etkinlikleri de açıklarken bu değişmez öz üzerinden veya başka bir deyişle kendinde olduğuna inanılan eğitimin özü, gönderim çerçevesi kabul edilmektedir. Eğitime özcü yaklaşım olarak da bilinen bu yaklaşımda, eğitim ile ilgili durumlar, söz konusu bu öz ya da idealle karşılaştırma yapılarak açıklamaya çalışan kuramların yanı sıra eğitim olgusunu, merkeze sorun çözmeyi koyarak öğrenme, düşünme, anlama, bireylerin gizil yeteneklerini ortaya çıkarma ve onların çok yönlü gelişmeleri için gerçekleştirilen etkinlikler ya da deneyimler üzerinden açıklayan kuramlarda vardır (Cevizci, 2011). İkinci yaklaşımda eğitimin, her toplum ve çağ için geçerli güç ve otorite ilişkilerine göre yeniden yapılandırılan ilişkisel bir gerçeklik olarak ele alındığı söylebilir. Eğitim olgusunu açıklamaya ilişkin benimsenen düşünsel ve bilimsel yaklaşımların farklılaşması, yürürlükteki eğitim etkinliklerinin yapı, işleyiş ve süreç boyutlarında, uygulamada ya da gerçek yaşamda deneyimlenen eğitimin ortaya çıkardığı veya ürettiği sonuçların bilimsel olarak değerlendirilmesini de değiştirecektir. Örneğin, birinci yaklaşımda, eğitim alanında yaşanan sorunlar, varsayılan ideal eğitim özünden bir sapma olarak değerlendirilebilirken ikinci yaklaşımda sorunun kaynağı güncel olan toplumdaki üretim, bölüşüm ve egemenlik ilişkileri dikkate alınarak bulunmaya ve çözülmeye çalışılacaktır.

Cevizci’ye (2011) göre alanyazında, eğitim sözcüğünün birbirinden farklı anlamlarda kullanımı söz konusudur. Analitik eğitim felsefecileri, bu farkın çeşitli bilimsel disiplinlerin eğitimi ele alışlarındaki farktan kaynaklandığını ileri sürmektedirler. Toplumbilim, eğitimi topluma uyum ve sorunsuz olarak topluma katılım; bireyin eğitim aracılığıyla toplumsallaşması ve toplumun kültürünü edinmesi gibi bir anlam ve içerik yükleyerek incelerken ekonomi, eğitimi ülkenin başta gereksinimlerini sonra da gönenç ve bolluğunu yaratmak üzere üretime ilişkin bir yatırım konusu olarak görmektedir. Kuşkusuz, ekonominin temel ve en önemli etmeni emektir. Bu anlamda emek ya da insangücü nitelikli duruma getirilmelidir. Eğitim sözcüğü, bazen okullaşma anlamında biçimsel eğitimde geçen süre olarak anlaşılırken bazen doğrudan okula, toplumsal bir kurum gönderme yapmak üzere kullanılmaktadır. Ancak, burada söz konusu eğitim sözcüğünün kullanımında, toplumbilim ve ekonomi disiplinlerinin ele alışlarında eğitim kavramı, daha çok temel eğitim ve mesleki eğitime çağrışım yapmaktadır. Eğitim sözcüğünün bir diğer kullanımında ise aydınlanma geleneğiyle gündeme gelen, aklın kullanımıyla eğitim arasındaki ilişkide kendini gösteren, eğitimli bireylerin madde ve insan evrendeki olgu ve olayları anlama ve değerlendirmesinde dogmatik olmayan eleştirel akılcı ilkelerle hareket etme anlamıdaki değişime vurgu yapılmaktadır. Bugün, toplumsal bir kurum olarak var olan eğitim, aydınlanmacı ya da eş deyişle modern seküler temeller üzerine kurulmuş ve buna göre içeriklendirilmiştir. Bu çalışmada eğitim sözcüğü, daha çok 
kurumlaşmış bir toplumsal yapıya, biçimsel eğitim kurumuna yani okul anlamında, daha sınırlı bir çerçevede ve anlamda kullanılmıştır.

İnsan türünün, doğadan bazen dolaysız olarak bazen de doğayı üretim araçlarıyla işleyerek elde ettiği ürünlerle gereksinimlerini giderdiği ve böylece varlığını sürdürdüğü bilinen bir gerçektir. İnsan gereksinimlerinin, en eski toplumlardan bugünün modern toplumlarına doğru giderek karmaşıklaşması ve çeşitlenerek gelmesi, üretimde kullanılan görece yeni yöntem ve tekniklere ilişkin geçmişte olduğundan daha çok bilginin aktarılmasını ve işlenmesini de beraberinde gerektirmiştir. İnsan gereksinimlerinin çeşitlenmesiyle birlikte, bu gereksinimlerin karşılanması için gerçekleştirilen üretim biçimi değişmiş ve tarihsel süreçte değişen üretim ve bölüşüm ilişkileri sonucunda eğitim, yetiştirme ve öğrenme gibi etkinlikler daha çok önemli duruma gelmiştir (Kurul, 2002). Özellikle, buharlı makinenin buluşuyla başlatılan ve gelişmesini sürdüren endüstriyel üretimin yanında, yakın zamandaki yeni buluşlarla tanık olunan bilgi ve teknolojideki baş döndürücü hız, son çeyrek yüzyılda işbölümüne göre üretim yapan toplumlarda mesleklerin giderek çeşitlenmesine yol açmıştır. Artık modern kapitalist toplumda bireylerin yaşamda kalma koşulu, geçmişte olduğu gibi tarım ya da hayvancılık yaparak ortaya çıkan ürünleri gereksinimlerini gidermek için tüketme ya da üretim fazlasını üretemediği ürünlerle pazarda değişime sokarak değil, geçerli bir meslek edinme ya da uzmanlaşmadan ve dolayısıyla daha kapsamlı bir eğitimden ve yetiştirmeden geçmektedir. Bu anlamda her dönem, sıkça dile getirilen gelecek kuşakların hangi yöntem ve tekniklerle, nerede ve nasıl yetiştirileceği, hangi bilgi, deneyim, değer ve niteliklerle donatılacağı ve bunları gerçekleştirmek için hangi kaynakların ne ölçüde ve nasıl kullanılacağı gibi sorular ve bu sorulara aranan yanıtlar da değişmiştir. Bu soruların yanıtları bir bakıma, toplumların sahip oldukları eğitim kurumlarının da ana karakterini yansitacaktır.

Adem (1997) modern toplumda eğitim kurumlarını; aile, çevre ve okul olmak üzere üç ana başlık altında değerlendirmiştir. Çocuklar, örgün eğitim yaşamına başlamadan önce aile kurumunda eğitim almaktadırlar. Sonrasında, çocuklar aileden farklı olarak bilgisayar, telefon, internet, televizyon gibi kitle iletişim araçlarının yanı sira sinema ve tiyatro gibi toplumsal alanlardan, yani çevreden öğrenmektedirler. Ancak, eğitim ve öğretime ilişkin bugünün en çağcıl kurumunun okul olduğunu dile getirmektedir. Gerçekten de, günümüz modern toplumlarında, eğitsel süreçlerin önemli bir bölümü biçimsel eğitim kurumlarında, eş deyişle okullarda gerçekleştirilmektedir.

Okullar ya da eğitim kurumları, insanlık tarihi boyunca elde edilmiş ve bugünlere katlanarak gelen bilgiyi ve deneyimi yeni kuşaklara belirli bir plan ve program gözeterek alanında yetiştirilmiş yetkin kişiler tarafından sistemli biçimde aktarmakla görevlidir. Kurumsal olarak eğitimin gerçekleştirmeye çalıştığ 1 bu görev, insan türünün ayakta durma veya başka bir deyişle yaşamda kalmasının olmazsa olmazı durumundadır. Çünkü, evrene ilişkin kimi zaman deneme yanılma ve kimi zamanda buluşlar yoluyla edinilen ve biriktirilen bilgi; örneğin toprağı işleme, ondan 
ürünler elde etme ve bu ürünleri işleyerek yararlı duruma getirme başta insan türünün biyolojik varlı̆̆ını sürdürmesinin temel koşuludur. İnsanın, doğayı işlemesi ve üretmesi somut varlıklara biçim vermesiyle birlikte en dar anlamda kültürün de ortaya çıktığı söylenebilir. Bu anlamda, hem yeni kültür üretme hem de kültürlenme etkinliklerinden biri de eğitimdir. Eğitim kurumu, bir yandan bireylere içinde bulundukları toplumun kültürünü verirken diğer yandan bireyleri toplumsallaştırmak, onları toplumun yönetim yapısıyla uyumlu, nitelikli birer insangücü olarak yetiştirmek ve benzeri işlevleri yerine getirmekle sorumludur (Bursalığlu, 1998). Genel olarak eğitimden beklenti; bireylere yerel ve evrensel değer ve kültürü kazandırma anlamında toplumsal, emeğe üretken nitelikler kazandırma anlamında ekonomik ve ülkede geçerli olan yönetsel yapı ve işleyişi benimsetme anlamında da politik görevleri yerine getirmesi olarak dile getirilebilir.

Dünyada gelişmiş olarak nitelendirilen ülke, toplum ve kültürlerin başarı kaynaklarına bakıldığında, bu gelişmişliklerine neden olarak sahip oldukları bilgi birikimlerini okullar aracılığıyla gelecek kuşaklara nitelikli bir biçimde aktarmalarından kaynaklandığı görülebilir (Dewey, çev. 1996). Ülkeler, ister toplumsal ve kültürel gelişme isterlerse de kalkınma, büyüme ve gelişme gibi ekonomi temelli paradigmalarla hareket etsinler eğitimin, konulmuş hedeflere erişmek için önemli bir belirleyen olarak bazen dolaylı bazende doğrudan olmak üzere hep denklemin içinde yer aldığı söylenebilir. Bu anlamda, söz konusu biçimsel eğitimin kurumlaştı̆ı toplumsal yapı olarak okul, toplumu oluşturan bireylere, söz edildiği gibi insanlığın ortaya çıkardığı ve beraberinde getirdiği birikim ve kültürünü aktarmanın yanı sıra onlara bütün toplumsal alanlarda örneğin ekonomik alanda ya da yaşamda da özne olarak var olmaları için gerekli eğitsel nitelikleri kazandırmayı amaçlamaktadır. Ekonomik yaşamda özne olmak ise temelde üretken, üretici olmaktan geçmektedir. Bireyler, yaptıkları üretimin değeri karşılığında ancak üretemediği diğer gereksinimi olan ürünlere erişebilmektedir. Ancak, ekonomik olarak öznelik, bireylerin tüketim konusunda da belirli düzeyde bilgi sahibi ve bilinç düzeyinde olmalarını gerektirmektedir. Karakütük (2012) eğitim ile ekonomi birbiri ile çok yakından ilişkili olduğunu belirterek, eğitimin bireylere kazandırdı̆̆ 1 niteliklerle üretimin verimliliğini artırdığını dile getirmektedir. Bu verimlilik artışı da üretime artış ve beraberinde ekonomide verimlilik artışı ortaya çıkarmaktadır. Bu yönüyle eğitim dizgesinin, genel söyleyişle okulun, bireylere özellikli bir üretim ve tüketim sağlaması ve bu yolla toplumsal gelişmişliğe ve mutluluğa da katkıda bulunmaya yönelik işlemesi beklenmektedir.

Eğitim dizgelerinin amacı, yapısı ve işleyişi, ülkeden ülkeye değişse bile her ülkenin özgün, belirli ilkeler çerçevesinde kurgulanmış ve yasalarla düzenlenmiş, eğitim aracılı̆̆ıyla yurttaşlara kazandırmak istediği eğitsel nitelikleri içeren genel amaçları ve bunun yanında özel amaçları bulunmaktadır (Tezcan, 1984). Eğitimle ilgili gereksinimler ve eğitimin özelliğini ise toplumların içinde bulundukları ekonomik ve politik koşullar, toplumsal ve kültürel birikimleri belirlemektedir (Aksoy, 2003). Türkiye'de eğitim dizgesinin genel amaçlarının yer aldığ 1 yasal metinlerde (Milli Eğitim Temel Kanunu, 1973 ss. 5101-5102; Devlet Planlama 
Teşkilatı, 1967), "iyi yurttaş yetiştirmek, toplumsal gönenci artırmak, toplumu çağdaş medeniyetler seviyesine ulaştırmak" gibi ifadeler yer almaktadır. İyi yurttaşlar yetiştirmek eğitimin toplumsal ve politik bir göreviyken ulusal geliri, gönenci artırmak üzere iyi üretici ve tüketiciler yetiştirmek de eğitimin ekonomik görevleri arasında sayılamaktadır. Ancak, eğitimin amaçları, süreç içinde yerel ve küresel ölçekte ortaya çıkan toplumsal, ekonomik ve politik değişimler ve gelişmelere göre yeniden düzenlenebilmektedir. Bu düzenlemeler bazen, karar vericiler tarafindan eğitimde yenilik hareketleri olabileceği gibi bazen de köklü devrim niteliğinde değişimler söz konusu olmaktadır. Toplumlar, eğitim dizgelerine ilişkin amaçlarını belirlerken genel çerçevede, toplumu oluşturan bireylerin bedensel ve zihinsel gereksinimlerini, gizli ve açık yeteneklerini, ilgileri ve içinde yaşadıkları doğal ve toplumsal alanları da göz önünde bulundurmaktadırlar. Başka bir deyişle toplumsal, kültürel, ekonomik ve politik alan ve yapılar dikkate alınmaktadır. Böylece eğitimin, tek tek bireylere, topluma, doğal çevreye ve bütün insanlığa dönük amaçlarını gerçekleştirebilmesi için sahip olunan olanaklar ile birlikte, kendine içinde bulunulan çağın gerekliliklerine uygun ve erişilebilir hedefler koyması gerektiği söylenebilir.

Türk Eğitim Dizgesi’nin genel ve özel amaçlarını gerçekleştirmek doğrultusunda hazırlanan her düzeydeki öğretim programları ve şimdiye dek yapılan kalkınma planları incelendiğinde, eğitim süreçleri içinde bireylere kazandırılması amaçlanan ekonomiyle ilgili eğitsel nitelikler açık biçimde göze çarpar. Eğitim dizgesinin yakın ve uzak hedeflerine ulaşması ve bu doğrultuda amaçlarını gerçekleştirmek üzere toplumsal ve ekonomik gelişime katkı sunacak önceden belirlenmiş eğitsel yeterlikleri olanaklar çerçevesinde bütün toplum üyelerine kazandırması beklenmektedir. Karakütük'e (1991) göre eğitim dizgesinin genel amaçları, bu dizgenin girdilerinden kabul edilen öğrencileri, iyi birer üretici ve tüketici olarak yurttaşlık bilinciyle yetiştirmek olarak özetlenebilir. Belirlenen amaçları gerçekleştirmek üzere eğitim dizgesi, ilköğretim, ortaöğretim ve yükseköğretim olmak üzere farklı eğitim düzeyleri için kurulmuş, düzenlenmiş ve uygun içeriklerle donatılarak işleyişse konulmuştur. Dahası, eğitimin genel amaçlarının yanında her eğitim düzeyinin kendine özgü özel amaçları belirlenmiştir. Bilindiği gibi, ilköğretimde, bireylere temel düzeyde okuma ve yazmanın, güzel konuşma gibi yeterliklerin kazandırılmasının yanı sıra insanlığın kalıtı olarak yeni kuşaklara bıraktığı fen, matematik ve sosyal bilimlere ilişkin bilgiler de temel düzeyde verilmektedir. Bu çalışmada, üzerinde önemle durulacak olan eğitsel süreçlerden ilköğretim düzeyinde, önceden belirlenmiş ekonomiyle ilgili üretkenlik ve tüketim bilincine sahiplik gibi ekonomiyle ilgili eğitsel niteliklerin öğrencilere kazandırılması ve bunun eğitimin genel ve özel amaçlarının gerçekleştirme derecesi üzerindeki etkisi ve belirleyiciliğidir.

Bilindiği gibi, Milli Eğitim Bakanlığı (MEB) tarafından ilköğretim ve ortaöğretim düzeyinde, var olan öğretim programların güncelleme çalışmaları, geçen öğretim yılı itibariyle başlatılmıştır. Türkiye'de eğitim, ilgili karar alıcılar tarafından bütün kamuoyunun görüş, eleştiri, öneri ve katkısına açılan öğretim programları, süreç içinde güncellenmiş ve 2017-2018 Eğitim-Öğretim yılından itibaren ilköğretim 
düzeyinde birinci ve beşinci sınıflardan başlayarak aşamalı olarak uygulamaya konulmuştur (MEB, 2018). Öğretim programlarında yapılan güncellemede, ilköğretim programlarında yer alan ekonomiyle ilgili eğitsel niteliklere ilişkin kazanımları yoğun olarak barındıran Türkçe, Matematik, Teknoloji ve Tasarım, Hayat Bilgisi, Sosyal Bilgiler derslerinin söz konusu kazanımlarında göze çarpan bir değişiklik görülmemektedir.

Schug ve Birkey'e (1985) göre, eğitimin ekonomiyle ilişkilendirilen içeriği, üretken ve katılımcı yurttaşlar yetiştirebilmek içindir. Bilindiği gibi bireylerin ekonomiyle ilgili başta kavram, düşünme yol ve yöntemleri öğrenmeleri ilköğretim programlarında geniş biçimde yer almaktadır. Hayta ve Akhan'a göre (2014) eğitim dizgesinde öğrenciler, yaş gruplarına uygun içerikle ekonomiyle ilgili gerekli kazanım ve özelliklerle donanmış olarak yetiştirilmelidirler. Türk Eğitim Dizgesi'nde ilköğretim düzeyinde eğitim, ekonomiyle ilişkili olarak; öğrencileri, geçerli olan meslekleri tanıyan, temel ekonomi sözcüklerini bilen, bireysel ve toplumsal kaynakları ülke ve ülkelerarası ölçünlere göre ve birincil gereksinimleri giderme yönünde etkili ve verimli biçimde, yüksek bir farkındalıkla kullanabilen, tutumlu, topluma, doğaya ve yasalara karşı yükümlülüklerini bilen üretken bireylere ulaştırmayı amaçladığı söylenebilir.

$\mathrm{Bu}$ çalışmada, araştırma konusu edinilen üretkenlik ve tüketim bilincine sahiplik gibi ilköğretim düzeyinde öğrencilere edindirilmesi beklenen ekonomiyle ilgili eğitsel nitelikler, önce eğitim ekonomisi alanyazınından ve Türikye'de yürürlükte olan eğitime iliş̧kin yasal metinlerinden daha sonra ise ilköğretim düzeyindeki ders içerikleri ve programları incelenerek belirlenmiştir. İlköğretim, diğer eğitim düzeylerinde olduğu gibi bir yandan öğrencilerin gizli yeteneklerini keşfetmelerine yardımcı olmaya çalışırken diğer yandan öğrencilere ekonomiyle ilgili temel bilgi ve beceriyi kazandırma, bu anlamda edinilen bilgi, beceri ve yeteneklerini gündelik yaşamda gereksinim duydukları alanlarda etkili olarak kulanmaları için uğraş vermektedir. $\mathrm{Bu}$ anlamda ilköğretimin, kapsam ve içeriğiyle öğrencileri, temel düzeyde birer ekonomik özne olarak, üretim ve tüketim etkinliklerinde beklenen tutum ve davranışlarla yetiştirmeyi amaç edindiği söylenebilir. Eğitim dizgesi, böylece çağcıl modern yaşamda ayakta kalmak ve varolmak üzere hazırladığı bireyleri; ekonomide kullanılan temel sözcükleri bilen, üretkenliğin ve üretimin anlam ve önemini anlamış, kişisel yeteneklerini ileride yapmak istediği meslekle ilişkilendirebilen, meslekleri tanıyan, kişisel istekleri ile gereksinimlerini birbirinden ayırt edebilen ve bu anlamda farkındalığ 1 yüksek, tüketim bilincine sahip bireyler olarak yetiştirmek istemektedir (MEB, 2018). İlköğretimde, öğrencilere kazandırılması amaçlanan ekonomi temelli eğitsel niteliklerden; üretkenlik ve tüketim bilincine sahiplik niteliklerini öğrencilere hangi ölçüde kazandırıldığının ve bu anlamda ortaya koyduğu amaç ve hedeflere ilköğretim düzeyinde eğitimin ulaşma derecesinin belirlenmesi bu çalışmanın problemini oluşturmaktadır.

Aksoy’a (2003) göre, Türkiye'de yürürlükteki eğitim dizgesini düzenleyen yasal metinlerde, eğitimin genelde ve özelde amaçlarını yerine getirme seviyesini 
saptamaya yarayan eğitsel göstergeler oluşturulması bir gerekliliktir. Ancak bu göstergeler kullanarak eğitimin amaç ve hedeflerine hangi ölçüde ulaşıldığına ilişkin daha sağlıklı değerlendirmelerde bulunulabilir. Buna örnek olarak eğitimle ilgili yasalar arasında, 1973 yılında çıkarılan 1739 sayılı yasa gösterilebilir. Özellikle, eğitimde toplumsal getirisi en yüksek öğretim düzeyi olarak görülen ilköğretim ya da temel eğitim düzeyinin, ağırlıklı olarak kamusal fonlarla yurttaşlara sunulduğu Türkiye'de, eğitime ayrılan kaynakların, yerinde veya uygun biçimde ve gereğince kullanılıp kullanılmadığı ancak eğitimin amaçlarını ne ölçüde gerçekleştirdiğini saptamaktan ya da bilmekten geçmektedir.

İlgili alanyazında, genel olarak eğitim düzeylerine göre öğrencilere kazandırılması amaçlanan ekonomiyle ilgili eğitsel niteliklere ve özelde ilköğretimin bu kazanımları öğrencilere edindirme düzeyini doğrudan ve dolaylı olarak inceleyen araştırmalara rastlamak olanaklıdır. $\mathrm{Bu}$ çalışmaya katkısı olacağı varsayılan çalışmalardan biri olarak örneğin, Sağlam'ın (2010) Sakarya'nın Ferizli ilçesinde, toplamda 23 dördüncü ve beşinci sınıf öğrencisiyle yaptığı nitel araştıma gösterilebilir. Bu çalışmada, Tutum, Yatırım ve Türk Malları Haftasında okulda öğrencilerin yaptıkları etkinliklerin ilgili haftanın amacına uygunluğunun saptanması amaçlamıştır. Araştırmaya göre, söz konusu hafta kutlamalarında yapılan etkinliklerin öğrencilerin, hem tüketimde yerli mallarını tercih etmelerinde hem de bu etkinlikler öğrencilerde tüketici sorumluluğu bilinci geliştirme konusunda olumlu etkileri olduğu sonucuna ulaşılmıştır.

Gülercan’ın (2007) gerçekleştirdiği, ilköğretim düzeyi öğretim programlarında yer alan İş Eğitimi dersine uygun olarak sunulan eğitiminin sonuçlarının öğrenci görüşlerine göre değerlendirilmesini amaç edinen araştırmaya göre; çalışmaya katılan öğrencilerin beşte dörtlük gibi büyük bir çoğunluğu İş Eğitimi derslerinin yararlı olduğunu düşünmektedir. Tarama modelinde yapılan araştırmaya katılan öğrencilere göre, İş Eğitimi derslerini veren öğretmenler, derste kullanılacak bir araya toplanmış üniteleri belirlerken öğrencilerin yetenek ve ilgilerini yeterli düzeyde hesaba katmamaktadırlar. Ancak, çalışmada, ilköğretimdeki İş Eğitimi derslerinin, öğrencilerin kendi yetenek ve ilgilerini keşfedip öğrenmelerinde, zaman, materyal ve enerji kullanımında savurganlık yapmama gibi olumlu alışkanlıklar edinmelerinde etkili olduğu sonucuna ulaşılmıştır. Ayrıca, İş Eğitimi dersinin, öğrencilerin iş yaşamını ve meslekleri tanımalarında, kendi mesleki ilgi ve yetenekleri keşfetmelerinde, günlük hayatta karşılaştıkları sorunları kolayca halletmelerinde, bir iş yapmış olmanın mutluluğunu hissetmelerinde, beğeni geliştirmelerinde ve eğitim sürecinde ortaya çıkardıkları ürünleri gündelik yaşamda da kullanabilmeleri üzerinde etkilidir. Yazıcıŏlu, Erdoğan, Şanlı ve Sağdıçoğlu Celep'in (2008) yaptıkları çalışmada ise Türkiye'de ve yurtdışındaki Teknoloji Eğitimi uygulamaları incelenmiş ve yeni yapılandırılan Teknoloji ve Tasarım dersinin ve bu ders eğitmenlerinin yetkinliğini artırmaya yönelik günün ve ülkenin koşullarını göz önünde bulunduran taslak bir program hazırlanması amaçlanmıştır. Çalışma bulgularında; Teknoloji ve Tasarım adıyla konulmuş dersin, ilköğretim öğrencilerine eğitsel açıdan uygun olarak hazırlandığı ve öğrencilerin, ders programına konulan bu ders sayesinde günlük 
yaşamda karşılaştıkları sorunları çözebilmeleri için çözüm yolu bulmakta çok daha hazırlıklı ve daha duyumlu duruma geldikleri bulgulanmıştır.

Pınarcı'nın (2007) ilköğretim düzeyinde öğrencilerin tüketim alışkanlıklarını saptamak için yaptığı çalışmanın bulgularında; ilköğretim okullarında gerçekleştirilen tüketici eğitiminin, öğrencilerin tüketime iliş̧kin bilgi derecesini artırdığı, bu eğitimin öğrencilerin tüketime ilişkin yanlış inanış ve tutumlarını değiştirerek düzeltilebilmesinde etkili olduğu bulunmuştur. Ayrıca araştırmada, eğitimin bütün düzeylerinde tüketici eğitimine alan açılması gerektiği ve öğrencilere doğru tüketim alışkanlıkları kazandırılmasında tüketici eğitiminin oldukça önemli olduğu sonuçlarına varılmıştır. Akyüz (2009) tarafından, 11 ile15 yaş aralığındaki ilköğretim altıncı, yedinci ve sekizinci sınıf öğrencilerinin tüketicilik bilinç derecesini ölçmek amacıyla yapılan çalışmada ise ilköğretim öğrencilerinin orta ve orta üst derecede tüketim bilincine sahip oldukları bulgulamıştır. Araştırmada; katılımcıların \% 61.2'sinin alışveriş yapmadan önce satın alacakları ürünün piyasadaki fiyatına baktıkları bulgulanmıştır. Öğrencilerin alışveriş yapmadan önce ürünlerin piyasa fiyatına bakmalarının en önemli nedeni olarak ise yapacakları alışverişin gelir ve giderlerine koşut olup olmadığını anlamak olarak ortaya koymuşlardır.

Sert'in (2002) çalışmasında, Ankara ilinin birbirinden farklı sosyo-ekonomik yerleşim yerlerindeki ilköğretim öğrencilerinin tüketici davranışlarının belirlenmesi amaçlanmıştır. Araştırmada, ilköğretim öğrencilerinin \% 60.5'inin ekonomik yaşamda birer tüketici olarak haklarını bildikleri yönünde bulguya ulaşılmıştır. Malbeleği ve Sağlam'ın (2013) ilköğretim dördüncü sınıf öğrencilerinin bilinçli tüketiciliğe yönelik görüşlerini belirlemeyi amaçladıkları araştırma, 21 öğrenciyle birlikte nitel araştırma yöntemi benimsenerek gerçekleştirilmiştir. Araştırmaya göre; araştırmaya katılan öğrencilerin bilinçli tüketicilik konusunda yeterli düzeyde bilgi sahibi oldukları ve öğrencilerin kendilerini birer bilinçli tüketici olarak kabul ettikleri sonucuna ulaşılmıştır. Danilane ve Marzano (2014) ise yaptıkları çalışmada, tüketici eğitimini, içerik olarak eğitim ile sürdürülebilir kalkınma arasındaki ilişkiyi göz önüne alarak bir değerlendirme yapmışlardır. Araştırmacılara göre, tüketici eğitimi, genel olarak topluma yararlar sağlamaktadır. Aktif ve daha iyi bilgilendirilmiş tüketiciler olarak yetiştirilen bireyler; sorumluluk duygusu gelişmiş, tüketimin yerel ve küresel ölçekte sonuçlarını ve etkilerinin farkındadırlar.

McGregor'un (2010) yaptığı İlköğretim Okullarında Tüketici Eğitimi başlıklı araştırmada ise temel eğitim düzeyinde tüketici eğitiminin etkilerini değerlendirmek üzere ölçütler tanımlanmaya çalışılmıştr. Araştırmacıya göre tüketici eğitimi, bireylerin tüketici olarak hak ve sorumlulukları bilmelerinde, kişisel kaynak yönetimlerini doğru yapmaları konusunda etkildir. Ayrıca, tüketici eğitimi öğrencilerin, bilinçli tüketime ilişkin bilgi, beceri ve tutumlarını olumlu yönde geliştirmektedir. Makela ve Peters'ın (2004) ergenlik dönemindeki öğrencilerle gerçekleştirdiği çalışmada; tüketici eğitimi, öğrencilerin tüketici hak ve sorumluluklarını ve tüketim ile ilgili farkındalıkları yükseltmekte etkili olduğu bulgulanmıştır. 


\section{Amaç ve Önem}

$\mathrm{Bu}$ çalışmanın amacı, Ankara ili merkez dokuz ilçesindeki ilköğretim okullarında öğrenimlerine devam eden sekizinci sınıf öğrencilerinin görüşlerinden yola çıkarak ilköğretimde ekonomiyle ilgili eğitsel niteliklerden üretkenlik ve tüketim bilincine sahiplik niteliklerinin öğrencilere hangi derecede kazandırıldığını belirlemektir. $\mathrm{Bu}$ amaca ulaşmak için şu soruya yanıt aranacaktır: İlköğretimde öğrencilere kazandırması amaçlanan, üretkenlik ve tüketim bilincine sahiplik eğitsel niteliklerine ilişkin öğrenci görüşleri nelerdir?

Tüm topluma yönelik olma niteliği taşıyan eğitimin, ekonomik ve politik yapı ve işleyiş üzerinde etki ve yararları olmasının yanı sıra bireysel yararlar da sağlamaktadır (Kurul, 2002). Bu yararlar, ekonomik yararlar olabileceği gibi politik ve toplumsal yararlarda olabilmektedir. Eğitimin daha çok özerkleşme, özerk bireyler ortaya çıkarma yönü yani bireylerin kendileri dışındaki güçler veya yapılar tarafından belirlenme etkisinden bağımsızlaşması ve bireylere eleştirel düşünme becerisini kazandırma gibi doğrudan ekonomik olmayan bireysel boyutta değerlendirilen olumlu sonuçlarından söz edilmektedir. Ayrıca, eğitim aracılığıyla elde ettikleri bilgiyi, deneyimi ve eleştirel düşünme becerisini, özel ve mesleki yaşamlarında kullanan bireyler, aynı zamanda içinde bulundukları toplumsal yaşama da daha çok katkıda bulunacaklardır (Cevizci, 2011). Eğitimin ortaya çıkardığı yarar ve sonuçlardan ya da olumlu çıktılarından biri de modern seküler eğitimin, bireyleri özerk kılması ve toplumu akılcılaştırmasının yanında üretime ilişkin verilen mesleksel eğitimle ortaya çıkan başta toplumun ana gereksinimleri giderme ve bunun öteside ekonomide bolluk ve gönenci artırmak olarak belirtilebilir. Üretim, üretime ilişkin bilginin ve tüketimin geçmişle karşılaştırılamayak derecede farklılaştığı bugünün modern toplumlarında, temel düzeyde de olsa bireylere ekonomik yaşam ile ilgili belirlenmiş nitelikleri kazandırmak önemlidir. Bu eğitsel niteliklerin kazanılması, birey ve toplumların sadece bugüne özgü değil ve geleceğe de yansıyacak yararlarını içeren ve önceleyen özellikler taşımaktadır.

Eğitim, bireylerin ve toplumların gönenç içinde yaşamalarını sağlayan ve gelişmişlik düzeyini gösteren en önemli etmenlerden biridir. Eğitimin genel amacının ilköğretim, ortaöğretim ve yükseköğretim gibi bütün düzeylerde kazanım olarak belirlediği eğitsel nitelikleri öğrencilere olabildiğince tam ve eksiksiz olarak edindirmek olduğu söylenebilir. Eğitimin amaçlarını yerine getirme düzeyini saptama girişimi ise ulusların eğitim aracılığıyla belirledikleri hedeflere ne kadar ulaştıklarının bilinmesi bakımından önemlidir. $\mathrm{Bu}$ araştırma, ulusların yakın ve uzak erimli hedeflerine ulaşmak için yaptıkları eğitim harcamaları ve bu başlık altında ilköğretim düzeyinde kullanılan bireysel ve toplumsal kaynakların yerinde, etkili ve verimli kullanılıp kullanılmadığına ilişkin yapılacak tartışmalara katkı sunması açısından ayrıca önemlidir. 


\section{Yöntem}

Çalışmanın yöntem başlığı altında sırasıyla; araştırma modeline, araştırma hedef evrenine ve bu evreni temsil edecek örnekleme, verilerin toplamasına ve çözümlenmesine ilişkin bilgiler ilgili başlıklar altında ayrıntılarıyla verilecektir.

\section{Araştırma Modeli}

Tarama modelinde gerçekleştirilen bu araştırma betimsel bir çalışma olarak gerçekleştirilmiştir. Tarama modelinde yapılan araştırmaların genel özelliklerinden söz etmek gerekirse; bu modelde yapılan araştırmalar önceden veya şu an ki durumu, olduğu biçimiyle betimlemeyi ya da açıklamayı amaç edinmiş bilimsel araştırma yaklaşımı olarak değerlendirilmektedir. Tarama modelinde yapılan araştırmalar için, Karasar (1995) araştırma konusu görüngü, kişi veya özdeğim, öz koşulları içinde ve olduğu üzere tanımlanması için çaba gösterildiğini belirtmektedir.

\section{Evren-Örneklem}

Nicel çalışmalarda, araştırma evreninden örneklem almanın ana güdülenmesi zaman ve maliyet olduğu söylenebilir. Ancak, örneklem alınırken veya büyük bir kitle nüfustan küçük parçalar, kümeler alırken temsil gücü yüksek örneklem almak gerekmektedir. Örneklemden elde edilen verilerden, eş deyişle küçük parçadan edinilen bilgilerden yola çıkılarak böylece büyük parça ya da bütüne ilişkin genellemeler yapılabilmektedir. Örneklem alma matematik biliminin olasılık kuramlarına dayanmaktadır (Neuman, çev. 2013).

$\mathrm{Bu}$ çalışmanın hedef evreni, 2011-2012 öğretim yılında Ankara'nın merkez dokuz ilçesinde öğrenimlerine devam eden $66 \quad 122$ ilköğretim sekizinci sınıf öğrencisinden oluşmaktadır. İlköğretim düzeyinde sekizinci sınıf, ilköğretim birinci sınıftan sekizinci sınıfa kadar ilköğretim düzeyi öğretim programlarında bulunan ekonomiyle ilgili genel kazanımların öğrencilere edindirilmiş olması beklenen son öğretim yılıdır ve bu anlamda araştırma hedef evreni ilköğretim sekizinci sınıf öğrencileri olarak belirlenmiştir.

Söz konusu hedef evrenin temsili ise tabakalı örneklem tekniği kullanılarak ve öğrencilere seçkisiz erişimle gerçekleştirilmiştir. Araştırmanın hedef evreninin temisilinde tabakalı örneklem alma tekniği kullanılmasının nedeni; bu teknik sayesinde alt evrenlerin örneklemde temsil edilme durumunun güvence altına alınmasıdır. Tabakalı örneklem almayı detaylandırarak açıklayan Balcı'ya (2001) göre, örneklem belirlenirken bütün alt tabakalardan ayrıca basit ve tarafsız örneklem alınarak yapılması gerekir.

Çalışmada sözü edilen ölçütler göz önüne alınarak yapılan tabakalı örneklem alma işleminde araştırmanın hedef evreni, önce Ankara İli merkez ilçe sayısına göre dokuz tabakaya ayrılmıştır. Daha sonra, örneklemdeki bütün alt grupların temsili için merkez ilçelerde yer alan bütün ilköğretim okullarının bir listesi çıkarılmıştır. Listedeki okullar örnekleme tarafsız ve rastlantısal olarak belirlenerek eklenmiştir. Böylece, araştırmanın hedef evrenindeki 66122 ögrenci, $\alpha=.05$ anlamlılık, \% 5 hata 
payı düzeyinde ve \pm 1 ortalama standart hata göz önünde bulundurulduğunda 382 katılımcıdan oluşan bir örneklemenin temsil edeceği öngörülmüştür (Balc1, 2001).

Tabakalı örnekleme yöntemiyle merkeze bağlı ilçelerde bulunan ilköğretim okullarındaki öğrenci sayıları dikkate alındığında evreni yeterli biçimde temsil edebilen 382 kişilik örneklem grubu söz konusu ilçelere toplam içindeki büyüklükleri oranında dağıtılmış ve her bir ilçeden ne kadar öğrencinin araştırmaya dahil edileceği ayrıca hesaplanmıştır. Araştırma örneklemine uygun olarak araştırmaya katılan öğrencilerin dokuz farklı ilçeye ve cinsiyet değişkenine göre dağılımları ve toplam içindeki yüzdelik oranları ayrıntısıyla Tablo 1'de gösterilmiştir.

Tablo 1

Katılımcıların İlçe ve Cinsiyet Değiş̧kenine Göre Dă̆ılımı

\begin{tabular}{|c|c|c|c|}
\hline \multirow[b]{2}{*}{ İlçe } & \multicolumn{2}{|c|}{ Cinsiyet } & \multirow[t]{2}{*}{ Toplam } \\
\hline & Erkek & $\mathbf{K} \mathbf{z z}$ & \\
\hline Altındağ & 17 & 16 & 33 \\
\hline Çankaya & 31 & 37 & 68 \\
\hline Etimesgut & 19 & 15 & 34 \\
\hline Gölbaş1 & 8 & 11 & 19 \\
\hline Keçiören & 37 & 35 & 72 \\
\hline Mamak & 27 & 26 & 53 \\
\hline Sincan & 25 & 20 & 45 \\
\hline Yenimahalle & 24 & 23 & 47 \\
\hline Pursaklar & 5 & 6 & 11 \\
\hline Toplam & 193 & 189 & 382 \\
\hline Toplam içindeki oran (\%) & 50.5 & 49.5 & 100 \\
\hline
\end{tabular}

$\mathrm{N}=382$

Tablo 1'de sunulduğu üzere, Ankara ili merkez ilçelerinden araştırmaya toplam içindeki oranı \% 49.5 olan $189 \mathrm{kız}$ ögrenci ve yine toplam içindeki oranı \% 50.5 olan 193 erkek öğrenci olmak üzere toplam 382 ilköğretim sekizinci sınıf öğrencisi katılmıştır.

\section{Veri Toplama Aracı}

$\mathrm{Bu}$ çalışmada örneklemdeki öğrencilerin ilköğretimde ekonomiyle ilgili kazandırılması amaçlanan eğitsel niteliklere ilişkin görüşlerini saptamak için araştırmacı tarafindan ilk bölümü kişisel bilgilerden, ikinci bölümü ise araştırma konusuna ilişkin ifadelerden oluşan bir anket hazırlanmıştır.

Anketin hazırlanması aşamasında önce araştırmanın amaçları doğrultusunda gerek yurt içi gerekse yurt dişında yapılmış ilgili araştırmalar incelenmiş başka bir deyişle alanyazın taraması yapılmıştır. Alanyazındaki araştırmaların incelenmesi sonucu 67 maddeden oluşan bir madde havuzu ortaya çıkmıştır. Taslak ankette ortaya çıkabilecek olası ifade hataları ve öğrencilerce anlaşılması güç olabilecek ifadelerin yeniden düzenlenmesi için 30 ilköğretim öğrencisiyle bir hazırlık çalışması 
yapılmıştır. Bu çalışma ile taslak ankette yer alan bazı maddeler, yazım ve anlatım açısından öğrenciler tarafından daha kolay anlaşılabilmesi için yeniden düzeltilmiş ve ilk aşamada anlaşılması güç 17 madde madde havuzundan çıkarılmıştır.

Ön hazırlık çalışmadan elde edilen 50 maddelik anket taslağı daha sonra kapsam ve görünüş geçerliliği sağlamak için alan uzmanlarının görüşlerine sunulmuştur. Uzman görüşlerine göre yeniden düzenlenen taslak anketin ölçme yeterliğini belirlemek amacıyla ön uygulaması, aynı evrende yer almayan yedi farklı ilköğretim okulunda 82 öğrenciyle yapılmıştır. Ön uygulamadan elde edilen verilere bu kez anketin yapı geçerliğini belirlemek üzere açımlayıcı faktör çözümlemesi uygulanmıştır. Açımlayıcı faktör çözümlemesinde ise çözümlemenin uygulanma koşulu (KMO değerinin 1.00'e yakınlı̆̆ı), örneklem yeterliğinin ölçülmesi amacıyla Kaiser-Meyer-Olkin (KMO) testi yapılmıştır.

Verilere yapılan KMO testi sonucu .63 olarak ortaya çıkmıştır. Büyüköztürk'e (2002) göre, verilere faktör çözümlemesinin uygulanabilmesi için KMO testi sonucu ortaya çıkan değerin .50'den büyük olması gerekir. Açımlayıcı faktör çözümlemesini uygulayabilmenin diğer bir koşulu ise ön uygulamadan elde edilen verilerinin normal dağı̆ım koşullarını sağlamasıdır. Verilerin normal dağılım koşulunu sağlayıp sağlamadığını test etmek için bu kez verilere Barlett's testi yapılmıştır (3817.80; p = $.000)$.

Ortaya çıkan bu sonuçlara göre, örneklem için açımlayıcı faktör çözümlemesi yapılması uygun bulunmuştur. Açımlayıcı faktör çözümlemesi sonucunda, madde toplam korelasyonu .45 'in altında kalan maddeler, birden fazla faktör altında toplanan ve aralarında .01 'lik fark olan maddeler anketten çıkarılmıştır. Yine Büyüköztürk'e (2002) göre faktör çözümlemesinde yapılacak madde seçiminde ölçüt, madde toplam korelasyon değerinin .45 'in üzerinde olmasıdır. Açımlayıcı faktör çözümlemesi sonucunda taslak anketten 11 madde çıkarılarak 39 maddelik araştırma anketine ulaşılmıştır. Bu çalışmada, araştırma için geliştirilen anketin sadece iki boyutu için toplam 19 ifadeye yönelik ilköğretim öğrencilerin katılımları değerlendirilmiştir. Yapılan ilgili çözümlemeler sonucunda, araştırmanın boyutlardan birincisi üretkenlik boyutuna ait açılanan varyans değeri \% 21.37 iken ikincisi, tüketim bilincine sahiplik boyutu için açıklanan varyans değeri \% 19.62 olarak ortaya çıkmıştır.

Anketin bütün boyutları için açıklanan toplam varyans değeri \% 61.26'dır. Anketin güvenirliği için ise Cronbach Alpha katsayısına bakılarak değerlendirilmiştir. Bütün anketin güvenirliği için yapılan test sonucunda $\alpha=.82$ olarak ortaya çıkmıştır. Kalaycı'ya (2006) göre, güvenirlik katsayısının .80 ile 1.00 aralığında çıkması araştırma anketinin yüksek derecede güvenilir olduğunu göstermektedir. Ayrıca bu çalışmada değerlendirmeye alınan her bir anket boyutu için yapılan güvenirlik testi sonuçlarına değinmek gerekirse, $\alpha$ güvenirlik katsayısı sırasıyla; üretkenlik boyutunda .84 ve tüketim bilincine sahiplik boyutunda .83 olarak ortaya çıkmıştır. Genel olarak ortaya çıkan değerlerine göre anketin geçerli ve güvenli olduğu kabul edilmiştir. 
İlköğretimde ekonomiyle ilgili eğitsel niteliklerin öğrencilere kazandırılmasıyla ilgili öğrenci görüşlerini belirlemek amacıyla hazırlanan anketteki ifadelere katılımın belirlenmesinde; 1 puan ile 5 puan arasında değişen Likert tipi derecelendirme kullanılmıştır. Likert tipi derecelendirmede ankette yer alan ifadeler; en yüksek katılımdan en düşük katılıma doğru; Tamamen katılıyorum (5 puan), Katılıyorum (4 puan), Kararsızım (3 puan), Hiç katılmıyorum (1 puan) ve Katılmıyorum (2 puan) biçiminde değerlendirilmiştir. Çalışmada, anket maddelerine verilen yanıtlardan elde edilen yüksek puanlar, ifadeye yüksek derecede katılım, düşük puanlarsa ifadeye ya da anket maddesine düşük derecede katılım biçimde yorumlanmıştır.

\section{Verilerin Toplanması ve Analizi}

Çalışmada çözümlenecek veriler araştırma için hazırlanan anket aracılığıyla toplanmıştır. Öğrencilere yapılan anket uygulaması ile elde edilen veriler bilgisayar ortamında çözümlenmiştir. Ankara'nın merkez dokuz ilçesindeki Devlet ve Özel okullarında öğrenimlerine devam eden sekizinci sınıf öğrencilerinin, ilköğretimde ekonomiyle ilgili eğitsel niteliklerin kendilerine kazandırılmasına ilişkin görüşleri, araştırma anketine verdikleri yanıtlardan elde edilen puanların aritmetik ortalama $(\bar{x})$, standart sapma (ss) değerleri ve katılım dereceleriyle yorumlanmıştır. Çözümleme sonucu çıkan ilgili değerlere göre öğrencilerin ankette yer alan bütün ifadelere katılım dereceleri ve her bir boyut için toplam katılım dereceleri belirlenmiştir.

\section{Bulgular}

$\mathrm{Bu}$ başlık altında, ilköğretimde kazandırılması amaçlanan ekonomiyle ilgili eğitsel niteliklere ilişkin öğrenci görüşlerine yönelik bulgular ve yorumlar sırasıyla; üretkenlik ve tüketim bilincine sahiplik niteliği boyutları için ayrı ayrı başlıklar altında verilmiştir.

\section{Üretkenlik Niteliğinin Kazandırılmasına İlişkin Görüşler}

Araştırma anketinin ilköğretimde ekonomiyle ilgili eğitsel niteliklerden, üretkenlik niteliği boyutunda yer alan dokuz ifadeye ilişkin öğrenci görüşlerinden elde edilen aritmetik ortalama, standart sapma ve katılım derecesi Tablo 2'de sunulmuştur.

Tablo 2

Üretkenlik Niteliğine İlişkin Öğrenci Görüşleri

\begin{tabular}{|c|c|c|c|c|}
\hline Nu. & İfadeler & $\overline{\bar{x}}$ & ss & Katılım Derecesi \\
\hline 1 & $\begin{array}{l}\text { Ürün tasarlama konusunda } \\
\text { etkinlikleri yeterli buluyorum. }\end{array}$ & 3.45 & 0.98 & Katıliyorum \\
\hline 2 & $\begin{array}{l}\text { Üretim yapmak için gerekli bütün bilgi, beceri } \\
\text { ve tutumu okulda edindiğimi düşünüyorum. }\end{array}$ & 3.49 & 1.03 & Kat1liyorum \\
\hline 3 & $\begin{array}{l}\text { Üretimde bilimsel bilgi ve teknolojinin } \\
\text { oldukça önemli olduğunu düşünüyorum. }\end{array}$ & 4.30 & 0.84 & Tamamen Kat1liyorum \\
\hline
\end{tabular}

(devam ediyor) 
Tablo 2 (devam)

\begin{tabular}{|c|c|c|c|c|}
\hline Nu. & İfadeler & $\bar{x}$ & $s s$ & Katılım Derecesi \\
\hline 4 & $\begin{array}{l}\text { Bir şey üretirken kullanacağım yöntem ve } \\
\text { teknikleri yeterince iyi öğrendim. }\end{array}$ & 3.73 & 0.95 & Kat1lyyorum \\
\hline 5 & $\begin{array}{l}\text { Okulda öğrendiklerim sayesinde yeterince } \\
\text { üretken olduğumu düşünüyorum. }\end{array}$ & 3.72 & 0.95 & Katıliyorum \\
\hline 6 & $\begin{array}{llll}\text { Üretim } & \text { aşamalarını } & \text { adım } & \text { adım } \\
\text { planlayabilecek } & \text { kadar } & \text { bilgi } & \text { edindiğimi } \\
\text { düsünüvorum }\end{array}$ & 3.67 & 0.97 & Katıliyorum \\
\hline 7 & $\begin{array}{l}\text { Üretim yaparken doğayı nassl etkilediğimiz } \\
\text { konusunda herhangi bir fikrim yoktur. }\end{array}$ & 1.71 & 0.87 & Hiç Katılmıyorum \\
\hline 8 & $\begin{array}{l}\text { Okulu üretim için gerekli olan nitelikleri } \\
\text { kazandırma konusunda yeterli görüyorum. }\end{array}$ & 3.53 & 1.03 & Katıliyorum \\
\hline 9 & $\begin{array}{l}\text { Okulda yeterince çalşşma alı̧skanlı̆̆ } \\
\text { kazandığımı düșünüyorum. }\end{array}$ & 3.72 & 1.00 & Katıliyorum \\
\hline
\end{tabular}

Tablo 2'de görüldüğü gibi, ilköğretim okullarındaki öğrencilerin üretkenlik niteliğine ilişkin ifadelere katılım derecelerine ilişkin aritmetik ortalamalar $(\bar{x}=1.71)$ ile $(\bar{x}=4.30)$ değerleri arasında değişmektedir. Araştırmada katılmcılar, üç numaralı ifadeye $(\bar{x}=4.30)$ Tamamen Katıllyorum derecesinde katılım göstermişlerdir. Bu ifadeye, öğrencilerin yüksek derecede katılımı; ilköğretimde bilimsel bilgiye ve teknolojiye gerekli önemin verildiği biçiminde yorumlanabilir. Öğrencilerin tablo 2'deki; bir numaralı $(\bar{x}=3.45)$, iki numaralı $(\bar{x}=3.49)$, dört numaralı $(\bar{x}=3.73)$, beş numaralı $(\bar{x}=3.72)$, altı numralı $(\bar{x}=3.67)$, sekiz numaralı $(\bar{x}=3.53)$ ve dokuz numaralı $(\bar{x}=3.72)$ ifadelere; Katıliyorum derecesinde katılım ortaya koydukları görülmektedir. Bu bulgular, öğrencilerin ilgili ifadelere orta üst derecede katıldıklarını göstermektedir. Çalışmada yapılan istatistiksel çözümlemeler sonucu ortaya çıkan değerler yorumlandığında; İlköğretimin, öğrencileri üretken duruma getirme ve üretken yeteneklerini ortaya çıkarma konusundaki etkinliğini yansıttığı düşünülen bu ifadelere öğrencilerin katılıyorum derecesinde yanıt vermeleri, ilköğretimin ekonomiyle ilgili üretkenlik niteliğini öğrencilere en azından bilgi düzeyinde kazandırmada etkili olduğu söylenebilir. Yine öğrenci görüşlerinden yola çıkarak ilköğretimin, kendilerine üretimin aşamalarının planlanmasını, bir şey üretecekken kullanacakları üretim yöntem ve tekniğine ilişkin bilgiyi, beceri ve tutumu ve çalışma alışkanlığını da kazandırma konusunda etkili olduğu söylenebilir.

Araştırma anketinde yedi numaralı $(\bar{x}=1.71)$ ifadeye, öğrencilerin verdikleri yanıtların Hiç Katılmıyorum derecesinde katılım göstermiş̧lerdir. Araştırma anketindeki bu ters yönde sorulmuş ifadeye öğrencilerin düşük derecede katılmaları; öğrencilerin, üretimin doğal çevreye olan olumlu/olumsuz etkilerinin yeterli derecede farkında oldukları biçiminde yorumlanabilir. Öğrencilere, anket aracılı̆̆ıyla sunulan ifade, üretkenlik eğitsel niteliğiyle ilgili olduğu gibi aynı zamanda kendilerinin gerçekleştirilen üretimin, insanın doğa ile kurduğu ilişki ve üretimin doğa üzerinde bıraktığı etkilerin de ne kadar farkında olduklarını anlamak bakımından dikakte değerdir. 


\section{Tüketim Bilincine Sahiplik Niteliğinin Kazandırılmasına İlişkin Görüşler}

Araştırma anketinin tüketim bilincine sahiplik boyutunda yer alan on ifadeye ilişkin öğrenci görüşlerine ait yapılan istatistik hesaplamalar sonucunda ortaya çıkan aritmetik ortalama, standart sapma ve katılım derecesi Tablo 3 'te gösterilmiştir.

Tablo 3

Tüketim Bilincine Sahiplik Niteliğine İlişkin Öğrenci Görüşleri

\begin{tabular}{|c|c|c|c|c|}
\hline Nu. & İfadeler & $\bar{x}$ & ss & Katılım Derecesi \\
\hline 10 & $\begin{array}{l}\text { Ürün satın alırken son kullanma tarihini her } \\
\text { zaman kontrol etmek gerekir. }\end{array}$ & 4.47 & 0.97 & Tamamen Kat1liyorum \\
\hline 11 & $\begin{array}{l}\text { Gereksinimlerimle isteklerimi birbirinden } \\
\text { kolayca ayırt edebileceğimi düşünüyorum. }\end{array}$ & 3.98 & 1.04 & Kat1liyorum \\
\hline 12 & $\begin{array}{l}\text { Satın alınan eşyanın Garanti Belgesi'ni } \\
\text { saklamak gereksizdir. }\end{array}$ & 1.92 & 1.39 & Kat1lmiyorum \\
\hline 13 & $\begin{array}{l}\text { Alacağım ürünün ilk önce kalitesine } \\
\text { bakmam gerekir. }\end{array}$ & 4.15 & 1.09 & Katıliyorum \\
\hline 14 & $\begin{array}{l}\text { Aldığım ürünle ilgili sorun yaşarsam } \\
\text { Tüketici Hakları Derneği'ne bildirmem } \\
\text { gerekir. }\end{array}$ & 4.25 & 1.08 & Tamamen Katıliyorum \\
\hline 15 & $\begin{array}{l}\text { Bir şeyi satın almadan önce fiyat } \\
\text { araştırması yapmak gerekir. }\end{array}$ & 3.90 & 1.20 & Katıliyorum \\
\hline 16 & $\begin{array}{l}\text { Medya ve iletişim araçlarının tüketim } \\
\text { üzerinde hiçbir etkisi yoktur. }\end{array}$ & 2.37 & 1.29 & Katılmiyorum \\
\hline 17 & $\begin{array}{l}\text { Bazı ürünleri gereksinimim olmasa bile } \\
\text { reklamını beğendiğim için aldığım olur. }\end{array}$ & 2.53 & 1.36 & Katılmiyorum \\
\hline 18 & $\begin{array}{lcl}\text { Okulda } & \text { edindiğim } & \text { kazanımlara göre } \\
\text { tüketim } & \text { konusunda } \\
\text { düşünüyorum. } & \end{array}$ & 3.61 & 1.20 & Katıliyorum \\
\hline 19 & $\begin{array}{l}\text { Bir şey alacağım zaman aile bütçemizi } \\
\text { dikkate almam gerekir. }\end{array}$ & 4.31 & 1.01 & Tamamen Kat1liyorum \\
\hline
\end{tabular}

Tablo 3'e dikkat edilirse, ilköğretim öğrencilerinin, tüketim bilincine sahiplik niteliğiyle ilgili ankette bulunan ifadelere katılım derecelerinin aritmetik ortalama puanları $(\bar{x}=1.92)$ ile $(\bar{x}=4.47)$ arasında değişmektedir. Öğrenciler bu boyuttaki; 10 numaralı $(\bar{x}=4.47), 13$ numaralı $(\bar{x}=4.15), 14$ numaralı $(\bar{x}=4.25)$ ve 19 numaralı $(\bar{x}=4.31)$ ifadelerine Tamamen Katıliyorum derecesinde, başka bir deyişle yüksek derecede katılım ortaya koymuşlardır. Bu ifadeler öğrencilerin yüksek derecedeki katılımları; ilköğretim öğrencilerinin tüketici olarak haklarının ne olduğunu bilme, satın aldıkları materyallerin son tüketim ve kullanım tarihine dikkat etme ve alışverişte aile gelir giderlerini dikkate alma gibi konularda ilköğretimin etkili olduğu söylenebilir.

Tablo 3'te görüleceği gibi, araştırmaya katılan öğrenciler, yine bu boyuttaki; 11 numaralı $(\bar{x}=3.98), 15$ numaralı $(\bar{x}=3.90)$ ve 18 numaralı $(\bar{x}=3.61)$ ifadelere ise Katılıyorum derecesinde görüş ortaya koymuşlardır. Öğrencilerin bu ifadelere katılma 
dereceleri ise yine, ilköğretim okullarında verilen eğitiminin, öğrencilerin tüketim bilincine sahip olmaları üzerinde etkili olduğu biçiminde yorumlanabilir. Ayrıca ilköğretim öğrencilerinin anketteki görüşlere katılım derecelerinden yola çıkarak; öğrencilerin gereksinimleri ile isteklerini orta üst derecede birbirinden ayırt edebilecek kadar farkındalık kazandıklarını düşünmekte oldukları söylenbilir.

Tablo 3 'te ayrıca öğrenciler, ters yönde sunulan 12 numaralı $(\bar{x}=1.92), 16$ numaralı $(\bar{x}=2.37)$ ve 17 numaralı $(\bar{x}=2.53)$ ifadelere Katılmiyorum derecesinde katılım göstermişlerdir. Öğrencilerin söz konusu ifadelere katılım derecesi ters yönde yorumlandığında; ilköğretim öğrencileri, gereksinimleri olmayan herhangi bir ürünü satın almamak gerektiğini ve gereksinimleri olan ürünleri ya da eşyaları satın aldıklarında ise aldıkları ürüne ait garanti belgesini saklamanın önemli olduğunu düşünmektedirler. Ayrıca yine öğrencilerin ilgili ifadeye katılım derecelerinden yola çıkarak ilköğretim öğrencilerinin, medya ve iletişim araçlarının tüketim üzerindeki etkilerinin farkında oldukları söylenebilir.

\section{Tartışma, Sonuç ve Öneriler}

Çalışmanın ilk boyutunda ilköğretimde öğrencilere edindirilmek istenen üretkenlik eğitsel niteliğini yeterince kazandıkları yönünde görüş belirten öğrenciler, sadece somut üretim anlamında değil tasarım yapma gibi soyut üretken becerilerini ortaya çıkarmak üzere yapılandırılmış eğitsel içeriğin ve süreçlerin etkili olduğunu düşünmektedirler. Bireylerdeki üretken becerilerin gün ışığına çıkarılmasında, okulların canlı ve cansız kaynaklar anlamında gerekli donanıma sahip olması; örneğin bugünlerde popüler olan kodlama atelyeleri ya da resim ve sanat atelyesi gibi eğitsel ortamların gereksinimlerinin saptanarak hızlı bir biçimde karşılanması gerekir. Öğrencilerin araştırma anketindeki ifadelere verdikleri olumlu yanıtlar, okullarda bu olanakların onlara tam sunulduğu anlamına gelmemektedir. Ayrıca, üretkenlik eğitsel niteliği, öğrencilerin özerk kişilik geliştirmeleri açısından çok önemli olduğu söylenebilir. $\mathrm{Bu}$ anlamda, üretkenlik niteliğini biraz açmak gerekirse, üretkenlik; çocukların zamanından uyanmasından, elini yüzünü yıkamasına, elbisesini giyerek güne hazırlık yapmalarına, okula ulaşmak üzere ulaşımı kullanmalarına, derslere katılımlarına, ders içi örneğin matematik veya fen bilgisi dersinde herhangi bir hesaplama yapmalarına ya da tasarım derslerinde önce soyut boyutta tasarladıklarını sonra somut ürün olarak ortaya çıkarmalarına kadar gerçekleştirdikleri birden çok etkinlik bu kavram kapsamında değerlendirilebilir. Üretkenlikten veya üretimden, doğrudan endüstriyel üretim veya bir mesleğe ilişkin yeterli nitelikleri kazandıktan sonra uzman düzeyinde yapılan iş ve etkinliklerde bulunmak anlaşılmamalıdır. Öğrencilerin, birey olarak bağımsız iş görmeleri, söz edilen daha geniş anlamda herhangi bir üretim etkinliğinde bulunmaları aynı zamanda bağımsız kişilik geliştirmeleri anlamında gelmektedir. Bu bakımdan, temel düzey eğitimde, üretkenlik eğitsel niteliğinin öğrencilere edindirilmesi yaşamsal öneme sahiptir.

Öğrencilerin araştırma anketindeki ifadelere katılım derecelerine göre çalışmanın bulguları genel olarak yorumlandığında; çalışmaya katılan öğrenciler, üretkenlik ve tüketim bilincine sahiplik gibi eğitsel niteliklerinin ilköğretimde 
kendilerine yeterli derecede kazandırıldığı görüşündedirler. Öğrenciler, üretimde bilimsel bilgi ve teknolojinin öneminin farkında olduklarını ve ürün tasarlama konusunda ilköğretimdeki etkinlikleri yeterli bulduklarını düşünmektedirler. Araştırmaya katılan öğrencilerin görüşlerine göre; ilköğretimin, öğrencileri üretime ilişkin bilgi, beceri ve tutum geliştirme konusunda yeterli derecede bilgilendirdiği ve gerekli tutum ve alışkanlıkları kazandırmada etkili olduğu sonunca varılabilir. Gülercan'ın (2007) çalışmasına göre; ilköğretimde yer alan İş Eğitimi dersi, öğrencilerin yaşamda karşılaştıkları sorunlara kolay çözümler bulabilmelerinde, bir iş yapmış olmanın mutluluğu ve kıvancını hissedebilmelerinde ve derslerinde yaptıkları işleri gündelik yaşamda kullanmalarında etkilidir. Bu çalışmanın bulgularıyla Gülercan (2007) ile Yazıcıoğlu ve dĭg. (2008) tarafından yapılan araştırmaların bulgularının benzerlik gösterdiği söylenebilir. İlgili araştırmalarca elde edilen bulgular 1şığında; öğrencilere göre ilköğretim, üretken olma niteliğini kendilerine edindirme konusunda etkilidir ve bu anlamda ilköğretimin öğrencileri yeterli derecede üretkenlik eğitsel niteliğiyle donattığı söylenebilir. İlköğretim, bir taraftan öğrencileri temel derecede üretken kılarken diğer yandan onların gizil yeteneklerini ortaya çıkarmakta ve öğrencilere temel düzeyde de olsa bir iş yapma alışkanlığı edindirmesi önemlidir.

Yine araştırma bulgularına göre öğrenciler, ilköğretimin, kendilerinin gündelik yaşamda karşılaştıkları sorunları daha kolay çözebilmeleri için yardımcı olmaktadır ve öğrenciler, bu çözümleri gerçek yaşamda da etkili olarak kullandıklarını düşünmektedirler. Eğitimde ilköğretim, herhangi bir mesleği yapmanın gerektirdiği bütün nitelikleri, davranış ve tutumu öğrencilere edindirmesi beklenen eğitim düzeyi değildir ancak öğrencilerin ilköğretim düzeyinde edindikleri ekonomik yaşam ile ilgili temel düzey bilgi, beceri ve nitelikler yaşam boyu geçerli ve kullanımda olmaktadır. Bundan dolayı öğrencilere erken çağlarda, temel düzeyde üretim becerisi kazandırma çalışmaları; hem düşünsel, soyut hem de somut üretime ilişkin gerekli bilginin verilmeye başlanması önemlidir.

Araştırmanın ikinci boyutuna ilişkin bulgulardan yola çıkarak öğrencilerin, ilköğretimde yine kendilerine yeterince tüketim bilincine sahiplik niteliğinin edindirildiği görüşünde oldukları söylenebilir. Sert (2002), Pınarc1 (2007), Sağlam (2010), Malbeleği ve Sağlam (2013), McGregor'un (2010) ile Makela ve Peters'ın (2004) yaptığı araştırmaların sonuçları; eğitimin öğrencilerin tüketime ilişkin bilgilerini geliştirme, tüketici olarak haklarını ve sorumluluklarının bilincinde olmalarına yardımcı olma, alışverişe çıkmadan tüketecekleri ürünlerin pazar fiyatını kontrol etme gibi tüketim bilincinin edinilmesine ilişkin bulgularıyla bu çalışmanın bulguları arasında benzerlikler söz konusudur. Öğrencilerin, gereksinimleri ile isteklerini birbirinden ayırt edebilme, ürünlerin son tüketim tarihine bakma, tüketimde kaliteli ürünü seçebilme, tüketimde medya ve iletişim araçlarının etkilerini bilme gibi tüketime ilişkin en temel konularda ilköğretimin, tüketim bilincini öğrencilere edindirme konusunda etkili olduğu sonucuna varmak olanaklıdır. İlköğretimin tüketim bilincine sahiplik niteliğini öğrencilere edindirmeye çalışması konusundaki bu çalışmanın bulgularıyla, Akyüz'ün (2009) yaptığı araştırmanın bulguları da 
benzerlik göstermektedir. Söz konusu araştırmaya katılan öğrencilerin büyük bir bölümünün gelir ve giderlerine göre alışverişe katıldıkları görüşünde oldukları bulgusu söz konusu araştırmanın bulgularıyla uyuşmaktadır. Ayrıca ilköğretim öğrencileri, enerji tasarrufuna yüksek derecede duyarlı olduklarını düşünmektedirler. Bunun yanı sıra öğrenciler, bireysel ve toplumsal anlamda varolan kaynakları yerinde ve gereğince kullandıkları görüşündedirler.

Eğitim bilimleri alanyazınında ilköğretimin bireyleri genel olarak iyi üretici ve iyi tüketici olarak yetiştirebilmesine vurgu yapılmaktadır. $\mathrm{Bu}$ vurgu eğitimin ekonomik görevinin bir gereğidir (Karakütük, 2012). Bu çalışmada da ilköğretimde ekonomiyle ilgili eğitsel niteliklerin öğrencilere kazandırılmasının sorunsallaştırması bir bakıma bireylerin genel olarak iyi yurttaş olmaları için özelde ise iyi birer üretici ve tüketici olarak yetiştirilip yetiştirilmediğini öğrencilerin görüşleri üzerinden sorgulanmaya çalışılmıştır. Günlük yaşamın önemli bir alanı olarak ekonomi ve bu toplumsal alanla ilgili etkinliklerde birer eyleyen olarak bulunması gerekli görülen öğrencilerin, öngörülen niteliklerle donanmış olmaları ya da başka bir deyişle üretken ve aynı zamanda tüketim bilinciyle hareket eden bireyler olmaları hem bireysel hem de toplumsal anlamda gelişmişliğe de katkıda sunacaktır. Öğrencilerin anılan niteliklere sahip bireyler olarak yetişmeleri, ilköğretim düzeyinde eğitimin ekonomiyle ilgili görevini hangi ölçüde yerine getirip getirmediğini de anlamaya çalışmaya yardımcı olmaktadır. İlköğretim düzeyinde yapılacak yeni araştırmalarda, nicel araştırma yaklaşımın kullanıldığı çalışmalarla elde edilecek sayısal verilerin yanında eğitsel gerçekliklerin daha derinlemesine anlaşılması için nitel araştırma yöntemlerinden de yararlanılması önerilebilir.

\section{Kaynakça}

Adem, M. (1997). Eğitim planlaması. Ankara: Şafak Matbaacılık.

Aksoy, H. H. (2003). Uluslararası karşılaştırma ölçütlerinin kullanımı ve Türkiye. Eğitim Bilim ve Toplum, 1(4), 51-60.

Akyüz, Z. (2009). İlköğretim çă̆ındaki öğrencilerin tüketim davranışları ve tüketicilik bilinç düzeyi (Yayımlanmış yüksek lisans tezi). Gazi Üniversitesi Eğitim Bilimleri Enstitüsü, Ankara.

Balc1, A. (2001). Sosyal bilimlerde araştırma: Yöntem, teknikler ve ilkeler (3. Baskı). Ankara: Pegem A Yayıncılık.

Bursalığlu, Z. (1998). Okul yönetiminde yeni yapı ve davranış (Genişletilmiş 7. Bask1). Ankara: Ankara Üniversitesi Eğitim Bilimleri Fakültesi Yayınları.

Büyüköztürk, Ş. (2002). Faktör analizi: Temel kavramlar ve ölçek. Kuram ve Uygulamada Ĕ̈itim Yönetimi Dergisi, 8(32), 470-483.

Cevizci, A. (2011). Eğitim felsefesi. İstanbul: Say Yayınları. 
Danilane, L., and Marzano, G. (2014). Consumer education in primary school in the context of sustainable development. Procedia - Social and Behavioral Sciences, 116, 1068-1072. doi: 10.1016/j.sbspro.2014.01.347

Devlet Planlama Teşkilatı. (1967). Íkinci beş yıllık kalkınma planı (1968-1972). Ankara. DPT Yayınları.

Dewey, J. (1996). Demokrasi ve eğitim [Democracy and education]. (S. Otaran, Çev.). İstanbul: Başarı Yayıncılık (Orijinal kitabın yayın tarihi 1916).

Gülercan, H. D. (2007). İstanbul ili ilköğretim okullarında uygulanan iş eğitimi ders programının değerlendirilmesi (Yayımlanmamış yüksek lisans tezi). Gazi Üniversitesi Eğitim Bilimleri Enstitüsü, Ankara.

Hayta, N. ve Akhan, N. E. (2014). İlköğretim sosyal bilgiler derslerinde ekonomi okuryazarlığının geliştirilmesi. Türkiye Sosyal Araştırmalar Dergisi, 18(1), 205 230.

Kalaycı, Ş. (2006). SPSS uygulamalı çok değişkenli istatistik teknikleri. Ankara: Asil Yayincilık.

Karakütük, K. (1991). Mesleki-teknik ortaöğretimin verimliliği. Ankara Üniversitesi Ĕ̈itim Bilimleri Fakültesi Dergisi, 24(2), 803-819.

Karakütük, K. (2012). Eğitim planlaması. Ankara: Elhan Kitap Yayın Dağıtım.

Karasar, N. (1995). Bilimsel araştırma yöntemi. Ankara: 3A Araştırma Eğitim Danışmanlık Ltd.

Kurul, N. (2002). Eğitim finansmanı. Ankara: Anı Yayıncılık.

Makela, C. J., and Peters, S. (2004). Consumer education: Creating consumer awareness among adolescents in botswana. International Journal of Consumer Studies, 4(28), 379-387.

Malbeleği, F. ve Sağlam, H. İ. (2013). İlkokul 4. sınıf öğrencilerinin bilinçli tüketiciliğe ilişkin görüşleri. Ondokuz Mayıs Üniversitesi Eğitim Fakültesi Dergisi, 32(1), 251-268.

McGregor, S. L. (2010). Consumer education as a site of political resistance: 50 years of conceptual evolutions from https://www.consultmcgregor.com/documents/publications/monograph_consu mer_education_2010.pdf

Milli Eğitim Bakanlığı (2018). Öğretim programları. http://mufredat.meb.gov.tr adresinden elde edilmiştir.

Milli Eğitim Temel Kanunu (1973). http://mevzuat.meb.gov.tr/html/88.html adresinden elde edilmiştir. 
Neuman, W. L. (2013). Toplumsal araştırma yöntemleri [Social research methods: Qualitative and quantitative approaches]. (S. Özge, Çev.). Ankara: Yayınodası (Orijinal kitabın yayın tarihi 2011).

Pınarcı, G. G. (2007). Illköğretim öğrencilerine farkl yöntemlerle verilen tüketici eğitiminin etkisinin belirlenmesi (Yayımlanmamış yüksek lisans tezi). Gazi Üniversitesi Eğitim Bilimleri Enstitüsü, Ankara.

Sağlam, H. İ. (2010). İlköğretim öğrencilerinin bilinçli tüketicilik düzeylerinin çeşitli değişkenler açısından incelenmesi. Kuram ve Uygulamada Ĕ̌itim Bilimleri Dergisi, 10(4), 2531-2568.

Schug, M., and Birkey, C. (1985). The development of children's economic reasoning. Theory and Research in Social Education, 13(1), 31-42.

Sert, P. (2002). İlköğretim öğrencilerinin tüketici davranışları (Yayımlanmamış Yüksek Lisans Tezi). Gazi Üniversitesi Eğitim Bilimleri Enstitüsü, Ankara.

Tezcan, M. (1984). Ĕ̌gitim sosyolojisi. Ankara: Çağ Matbaası.

Yazıcıoğlu, Y., Erdoğan, S., Şanlı, S. ve Sağdıçoğlu Celep, A. G. (2008). Ülkemizde ve dünyada teknoloji tasarım eğitimi. Art-E Journal of Faculty of Arts, 2, 9-13. 


\title{
Views of Students Regarding Educational Qualifications Linked to Economics Gained in Primary Education ${ }^{1}$

\begin{tabular}{cccc}
\hline ARTICLE TYPE & Received Date & Accepted Date & Published Date \\
Research Article & 11.02 .2018 & 04.30 .2019 & 05.01 .2019 \\
\hline
\end{tabular}

Hakkı Toy

Ankara University

\begin{abstract}
The purpose of this study was to determine the degree to which students in elementary schools gained educational qualifications related to social economics such as productivity, and consumption awareness. The target population for this study was composed of students from elementary schools throughout nine districts located in Ankara, Turkey during the 2011-12 academic years. In this study a scanning model and quantitative analysis was utilised. An accurate representation of the target group was achieved through stratified sampling of 382 students studying at elementary schools from districts located in central Ankara. Data regarding students' opinions were collected via a questionnaire developed specifically for this purpose. The study data were analysed and the arithmetic mean $(\bar{x})$ as well as standard deviation (sd) values were calculated. According to the results of the research based on the views gained from students, it was determined that the educational qualifications related to social economics such as productivity, and consumption awareness did increase through the students' elementary school education.
\end{abstract}

Keywords: Educational qualifications, being productive, consumption awareness.

${ }^{1}$ Toy, Hakk1 (2012) This article is produced from the master dissertation, named "The Opinions of Students about Gaining Educational Qualifications Based on Economy in Primary Education" completed in guaidance of Prof. Dr. Kasım Karakütük, Ankara University Institute of Educational Sciences.

${ }^{2}$ Corresponding Author: Ph.d. Student, Institute of Education Sciences, Department of Educational Administration and Policy, E-mail: hakkitoy@ hotmail.com, https://orcid.org/0000-0002-2440-825X 


\section{Purpose and Significance}

It is important to determine the educational qualifications linked to economics that are provided in elementary school programs. Elementary schools should assist students in gaining knowledge and skills related to economics such as being productive, and having awareness of consumption behaviour.

Schools or educational institutions have been tasked with systematically transferring the knowledge and experience that has been acquired throughout the history of humanity to the new generations by considering the specific plan and program by the skilled people trained in the field. This task, which the institution is trying to realize as a corporate, is the indispensable part of the human species to survive or to live in other words. Because information about the universe that is acquired and accumulated through trial and inaccuracy and sometimes through inventions; For example, processing the soil, obtaining products from it and making them useful by processing these products are primarily the basic condition for the human species to maintain its biological existence. It can be said that culture has emerged in the narrowest sense with the way that human beings process and produce nature and form concrete assets. In this sense, education is one of the activities of both new culture and culturing. The educational institution, on the one hand, is responsible for socializing individuals, giving them the culture of the society they are in, on the one hand, educating them as a qualified manpower in harmony with the management structure of the society and performing similar functions (Bursalığlu, 1998). Expectations from education in general; It can also be expressed as the accomplishment of political duties in the sense of adopting the economic structure and the political structure that is valid in the country in terms of gaining productive qualities in social and effort in terms of gaining local and universal value and culture.

When we look at the sources of success of the countries, societies and cultures, which are characterized as developed in the world, it can be seen that they lead their development as a result of their qualified transfer to future generations through the schools (Dewey, trans. 1996). It can be said that the countries, whether they want social and cultural development, progress with economic based paradigms such as development, growth and development. In this sense, the school as the social structure in which the formal education is institutionalized, as well as the individuals, as well as the accumulation and culture that humanity values about and the knowledge and culture that it brings with it, as well as the necessary training for them to exist as subjects in all social fields, for example in the economic field or in life, aims to gain educational qualifications. Being a subject in economic life is basically productive and becoming a producer. Individuals have access to the products with other requirements that they cannot produce in return for the value of their production. However, the economic subject requires individuals to have a certain level of knowledge about consumption and be conscious. Karakütük, (2012) states that education and economy are very closely related to each other and that education increases the efficiency of production with the qualities that are provided to 
individuals. This increase in productivity also leads to an increase in production and an increase in productivity in the economy. In this respect, it is expected that the education system, in general terms, will provide a special production and consumption to individuals and thus contribute to social development and happiness.

Education is one of the most important factors that enable individuals and societies to live in prosperity and show their level of development. It can be said that the general aim of the education is to achieve as much as possible and complete the educational qualifications that are determined as gain in all levels such as primary, secondary and higher education. The attempt to determine the level of fulfillment of the objectives of education is important in order to know how far the nations have reached their targets through education. This research is also important in terms of contributing to the debates on whether the educational expenditures of the nations to achieve their near and far-reaching targets and whether the individual and social resources used at the primary level under this heading are used effectively, and efficiently.

The purpose of this study was to determine the degree to which educational qualifications related to economics were gained by students in elementary schools. In order to gain insight into students' opinions the following question was asked: What are the views of students regarding the educational qualifications which are linked to economics; for example, being productive, and having consumer awareness, which are provided to students in elementary schools?

\section{Method}

This research was carried out using a descriptive survey model. Quantitative research methodology was utilised in this research. The objective population of this study was comprised of 66.122 eighth grade students who attended public and private elementary schools in nine districts located in the province of Ankara, Turkey during the 2011-12 academic years.

\section{Results}

The findings of the research revealed that according to students' views, their elementary school education did provide the requisite instruction necessary to develop and improve their knowledge and skills related to economics such as being productive, and consumption awareness. Also, the study findings revealed that according to the elementary school students' views, the elementary schools had achieved the goal of adequately providing students with basic production skills and work habits. It was determined that the elementary school students' were sufficiently productive and became more aware of consumer behaviour. In addition, it was determined that the students believed they were adequately educated regarding the quality of being frugal. Students were sensitive about energy saving and about using resources appropriately. 


\section{Discussion and Conclusions}

It is clear that effect on economic, political structure, and on the whole society, also education provides individual benefits (Kurul, 2002). These affect appearance economic benefits, as well as political and social benefits. Some of these are mentioned about the outputs of education which are evaluated in the non-economic individual dimension such as autonomization, autonomous individuals, the fact that the individuals are independent from the effect of determination by the forces or structures other than themselves and gain the ability of critical thinking to individuals. In addition, individuals who use their knowledge, experience and critical thinking skills in their private and professional lives through education will also contribute more to their social life (Cevizci, 2011). Some of the benefits and conclusions or positive outcomes of education is that modern secular education makes individuals autonomous and rationalize the society, as well as the development of occupational training with respect to production, in particular, to eliminate the main needs of society and furthermore to increase abundance and prosperity in the economy. In today's modern societies where production, information about production and consumption are differentiated by comparison with the past, it is important to provide individuals with qualifications related to economic life, albeit at basic level. The acquisition of these educational qualifications has priorities that include the benefits of individuals and societies that are not only specific to today, but also to the future.

When the educational programs at all levels prepared in line with the general and specific objectives of the Turkish Education System and the development plans made so far are examined, the educational qualifications related to the economy intended to be introduced to the individuals in the education processes are obvious. It is expected that the education will reach all the members of the community within the framework of the possibilities to reach the close and distant targets and in this direction the predetermined educational competences that will contribute to the social and economic development.

Elementary schools should provide students with knowledge of basic life skills, should help them discover their hidden abilities, and increase these types of knowledge, skills, and abilities so that students can be successful in their everyday life. Elementary schools should aim to provide their students with a set of attitudes and behaviours related to basic economic activities such as production and consumption that they can rely on as the future economic actors of society. Education should play an important role in preparing students for the economics of their future life, such as; preparing them for existence and survival in the modern world, understanding the basic terminology of economics, understanding the importance of productivity and production, improving their personal abilities, relating their personal needs and requirements to others, and also identifying their personal needs and requirements.

The results of this study revealed that according to the students' views, their elementary schools fulfilled the purpose to providing the educational qualifications of 
being productive, and having consumption awareness. It appears that the elementary schools were very effective in providing students with practical solutions for solving issues they may encounter in daily life. It is clear that elementary schools are not vocational based schools but they can provide educational qualifications regarding economics. As a result, it was significant that the basic production skills intended for children should begin in their primary school education. In addition, elementary schools should be able to educate students about being good producers as well as good consumers. In this sense, it is very important to start economics linked education and provide the related educational qualifications at an early age. 